\title{
Pengaruh BI Rate, Dana Pihak Ketiga, Net Interest Margin, terhadap Laba Bersih di Perusahaan Perbankan yang Terdaftar di Bursa Efek Indonesia Periode 2013- 2016
}

\author{
Chandra \\ Universitas Prima Indonesia \\ Chandrateja138@gmail.com \\ Kevin Samuel Manalu \\ Universitas Prima Indonesia \\ kevinsamuelmanalu97@gmail.com \\ Tulungan \\ Universitas Prima Indonesia
}

\author{
Januaryo Silalahi \\ Universitas Prima Indonesia \\ Januaryosilalahi@gmail.com \\ Theresia Princess Claudya \\ Universitas Prima Indonesia \\ Theresia.cava@gmail.com \\ Vania \\ Universitas Prima Indonesia \\ , Vaniatan97@gmail.com
}

\begin{abstract}
Abstrak
Penelitian ini bertujuan untuk menguji BI Rate, Dana Pihak Ketiga, Net Interest Margin, terhadap Laba Bersih di Perusahaan Perbankan yang Terdaftar Di Bursa Efek Indonesia Periode 2013-2016. Sampel penelitian ini diperoleh 92 perusahaan yang terseleksi menggunakan purposive sampling dengan kriteria tertentu. Hasil penelitian secara parsial menunjukkan bahwa BI Rate tidak berpengaruh terhadap laba bersih Sedangkan Dana Pihak Ketiga dan Net Interest Margin berpengaruh positif dan signifikan terhadap Laba Bersih. Secara simultan BI Rate, Dana Pihak Ketiga dan Net Interest Margin secara simultan berpengaruh signifikan terhadap Laba Bersih pada perusahaan sektor perbankan yang terdaftar di Bursa Efek Indonesia pada tahun 2013 - 2016.
\end{abstract}

Kata Kunci : BI Rate, Dana Pihak Ketiga, Net Interest Margin dan Laba Bersih.

\section{Abstract}

This study aims to examine BI Rate, Third Party Funds and Net Interest Margin to Net Profit on banking sector companies listed on the Indonesia Stock Exchange in 2013-2016. The research sample was obtained by 92 selected companies using purposive sampling with certain criteria. The results of the study partially indicate that BI Rate doesn't significant effect on Net Profit while third party funds and Net Interest Margin has a positive effect and significant on Net Profit. Simultaneously BI Rate, Third Party Funds and Net Interest Margin simultaneously have a significant effect on Net Profit on Banking sector companies that are listed on the Indonesia Stock Exchange in 2013-2016.

Keywords : BI Rate, Third Party Funds, Net Interest Margin and Net Profit. 


\section{PENDAHULUAN}

Setiap Bank harus memiliki kemampuan yang seimbang dalam mengelola simpanan yang diperoleh dari masyarakat dan menyalurkan dana kepada masyarakat dalam bentuk kredit. Hal tersebut dapat mempengaruhi kinerja Bank khususnya laba yang diperoleh bank tersebut. Masing-masing bank akan menggunakan strategi dan action plan untuk dapat mengelola bisnis bank itu sendiri.

Bi Rate salah satu instrumen yang digunakan oleh pemerintah dalam mengelola dan menjaga stabilitas keuangan dan kurs di Indonesia. Bi Rate juga dapat mempengaruhi kinerja bank, karena BI Rate menjadi acuan bagi Bank dalam menetapkan suku bunga simpanan dan kredit.

Kesehatan Bank merupakan cerminan dari kondisi bank saat ini dan di waktu yang akan datang. Sehat tidaknya perbankan dilihat melalui laba bank itu sendiri, karena tujuan perbankan adalah mencapai laba yang optimal. Hal tersebut guna meningkatkan kepuasam pada stakeholder mereka.

Saat ini Regulator mewajibkan semua bank untuk memberikan suku bunga murah kepada para pengusaha UMKM. Hal ini bertujuan agar masyrakat lebih produkti sehingga dapat meningkatkan pertumbuhan ekonomi. Hal ini juga menjadi tantangan bagi semua bank untuk menjaga kinerja \& profitabilitasnya. Perbankan juga akan mereview kembali laporan keuangannya dari tahun ke tahun, untuk mengetahui adanya penurunan maupun kenaikan BI Rate, DPK, NIM yang akan digunakan untuk mengetahui pengaruhnya terhadap laba bersih.

Dari data Otoritas Jasa Keuangan (OJK) sampai Februari 2017, laba bersih perbankan secara keseluruhan naik sebesar $12,23 \%$ menjadi Rp20,14 triliun dibandingkan dengan periode sama pada tahun lalu. Meskipun begitu, rasio net interest margin (NIM) perbankan mengalami penurunan menjadi 5,28\% dibandingkan dengan Februari 2016 yang sebesar 5,47\%. Adapun Presiden Direktur PT Bank Central Asia Tbk. Jahja Setiaatmadja menjelaskan, penurunan NIM yang terjadi pada awal tahun ini terjadi seiring dengan lanjutan penurunan bunga kredit. 
Tabel I.1

Fenomena Penelitian

(Dalam Jutaan Rupiah)

\begin{tabular}{|c|c|c|c|c|c|c|}
\hline $\begin{array}{l}\text { Kode } \\
\text { Emiten }\end{array}$ & $\begin{array}{c}\text { Nama } \\
\text { Emiten }\end{array}$ & Periode & $\begin{array}{c}\text { BI } \\
\text { Rate }\end{array}$ & $\begin{array}{l}\text { Dana Pihak } \\
\text { Ketiga }\end{array}$ & $\begin{array}{c}\text { Pendapatan } \\
\text { Bunga }\end{array}$ & $\begin{array}{c}\text { Laba } \\
\text { Bersih }\end{array}$ \\
\hline \multirow{4}{*}{ BBKP } & \multirow{4}{*}{$\begin{array}{c}\text { PT. Bank } \\
\text { Bukopin, } \\
\text { Tbk }\end{array}$} & 2013 & $7.50 \%$ & 55.822 .392 & 2.443 .840 & 934.622 \\
\hline & & 2014 & $7.75 \%$ & 65.390 .790 & 2.473 .400 & 726.808 \\
\hline & & 2015 & $7.50 \%$ & 76.163 .970 & 2.897 .438 & 964.307 \\
\hline & & 2016 & $4.75 \%$ & 83.869 .295 & 3.593 .050 & 1.090 .635 \\
\hline \multirow{4}{*}{ BDMN } & \multirow{4}{*}{$\begin{array}{c}\text { PT. Bank } \\
\text { Danamon } \\
\text { Indonesia, } \\
\text { Tbk }\end{array}$} & 2013 & $7.50 \%$ & 109.161 .182 & 13.531 .043 & 4.159 .320 \\
\hline & & 2014 & $7.75 \%$ & 116.495 .224 & 13.679 .836 & 2.682 .662 \\
\hline & & 2015 & $7.50 \%$ & 115.141 .528 & 13.648 .234 & 2.469 .157 \\
\hline & & 2016 & $4.75 \%$ & 103.739 .516 & 13.779 .021 & 2.792 .722 \\
\hline \multirow{4}{*}{ MEGA } & \multirow{4}{*}{$\begin{array}{l}\text { PT. Bank } \\
\text { Mega, Tbk }\end{array}$} & 2013 & $7.50 \%$ & 52.372 .043 & 2.696 .051 & 632.550 \\
\hline & & 2014 & $7.75 \%$ & 51.021 .875 & 2.745 .049 & 697.981 \\
\hline & & 2015 & $7.50 \%$ & 49.739 .672 & 3.302 .818 & 1.238 .769 \\
\hline & & 2016 & $4.75 \%$ & 51.073 .227 & 3.487 .634 & 1.545 .423 \\
\hline
\end{tabular}

Sumber : $\underline{\text { http://idx.co.id }}$

Berdasarkan tabel I.1 di atas, diperoleh gambaran data perbankan dapat dilihat pada PT. Bank Bukopin, Tbk yang memiliki dana pihak ketiga pada tahun 2014 sebesar Rp 65.390.790 mengalami peningkatan dibandingkan tahun 2013 dengan laba bersih pada tahun 2014 sebesar Rp 726.808 mengalami penurunan dibandingkan tahun 2013.

PT. Bank Danamon Indonesia, Tbk memiliki pendapatan bunga pada tahun 2014 sebesar Rp 13.679.836 mengalami peningkatan dibandingkan dengan tahun 2013 dengan laba bersih pada tahun 2014 sebesar Rp 2.682.662 mengalami penurunan dibandingkan tahun 2013.

PT. Bank Mega, Tbk BI rate mengalami kenaikan menjadi $7.75 \%$ pada tahun 2014 dibandingkan dengan tahun 2013 dengan laba bersih pada tahun 2014 sebesar Rp 697.981 mengalami kenaikan dibandingkan dengan tahun 2013.

\section{KAJIAN PUSTAKA}

\subsection{Pengertian $B I$ rate}

Menurut Tri Hendro ( 2014 ), BI Rate adalah suku bunga kebijakan yang mencerminkan sikap kebijakan moneter yang ditetapkan BI dan diumumkan kepada Publik.

Menurut Naf'an ( 2014 ), Bi rate adalah tingkat suku bunga nyang ditetapkan oleh Bank Indonesia.

Indikator BI Rate dalam penelitian ini adalah suku bunga acuan yang ditetapkan oleh Bank Indonesia pada bulan Desember 2013-2016.

\subsection{Pengertian Dana Pihak Ketiga}

Menurut Nuritomo (2014), DPK merupakan kewajiban bank kepada penduduk dan bukan penduduk dalam rupiah dan valuta asing.

Menurut I Wayan (2013), DPK merupakan utang bagi bank sehingga pada saatnya dana tersebut ditarik oleh masyarakat. 
Menurut Kasmir (2011), untuk memperoleh dana dari masyarakat luas bank dapat menggunakan tiga macam jenis simpanan (rekening).

Sumber dana yang dimaksud adalah sebagai berikut.

1. Simpanan giro

2. Simpanan tabungan

3. Simpanan deposito

\subsection{Pengertian Net Interest Margin}

Menurut Pandia (2012:71), net interest margin adalah rasio yang digunakan untuk mengukur kemampuan manajemen bank dalam mengelola aktiva produktifnya untuk menghasilkan pendapatan bunga bersih.

Menurut Ikatan Bankir Indonesia (2017:317), net interest margin (NIM) margin bunga bersih adalah ukuran perbedaan antara bunga pendapatan yang dihasilkan oleh bank atau lembaga keuangan lain dan nilai bunga yang dibayarkan kepada pemberi pinjaman mereka (misalnya depositor), relatif terhadap jumlah mereka (bunga produktif) aset. Hal ini mirip dengan margin kotor perusahaan nonfinansial.

Menurut Sofyan (2016), rasio ini menunjukkan kemampuan earning assets dalam menghasilkan pendapatan bunga bersih.

$$
N I M=\frac{\text { Interest income }- \text { Interest Expense }}{\text { Average Interset Earning Assets }} \times 100 \%
$$

$\mathrm{NIM}=$ Net Interest Income

\subsection{Pengertian Laba Bersih}

Menurut Ikhsan (2012) Laba bersih adalah kenaikan dalam modal yang dihasilkan dari keuntungan operasi bisnis.

Menurut Sofyan (2016), laba bersih menggambarkan kemampuan perusahaan mendapatkan laba melalui semua kemampuan, dan sumber yang ada seperti kegiatan penjualan, kas, modal, jumlah karyawan, jumlah cabang, dan sebagianya.

Menurut Dewi (2014:63), laba bersih ialah kemampuan manajemen untuk memperoleh laba

Menurut Wira (2014), adapun rumus laba bersih adalah sebagai berikut:

Laba bersih=Laba Operasi -Beban LainLain - Pajak

\section{Gambar 1. Kerangka Konseptual}

Adapun kerangka konseptual dalam penelitian ini adalah:

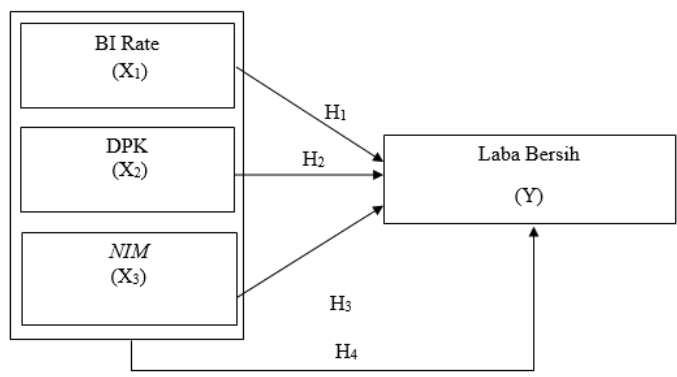

Berdasarkan batasan dan rumusan masalah, terdapat dua hipotesis yang dapat digunakan yaitu hipotesis simultan dan hipotesis parsial maka dibuat hipotesis penilitian sebagai berikut BI Rate, Dana Pihak Ketiga, dan Net Interest Margin secara simultan berpengaruh signifikan terhadap Laba Bersih pada Perusahaan Perbankan yang Terdaftar Di Bursa Efek Indonesia Periode 2013-2016.

\section{METODE PENELITIAN}

Penelitian ini menggunakan analisis regresi linear berganda. Model regresi linear berganda yang digunakan adalah sebagai berikut:

$$
Y=a+b_{1} X_{1}+b_{2} X_{2}+b_{3} X_{3}+e
$$

Keterangan : 


$$
\begin{array}{ll}
\mathrm{Y} & \text { : Laba Bersih } \\
\mathrm{a} & \text { : konstanta } \\
\mathrm{X} 1 & \text { : BI Rate } \\
\mathrm{X} 2 & \text { : Dana Pihak Ketiga } \\
\mathrm{X} 3 & : \text { Net Interest Margin } \\
\mathrm{b}_{1,2,3} & \text { : Besaran koefisien regresi dari } \\
& \text { masing-masing variabel } \\
\mathrm{e} & \text { : error }
\end{array}
$$

\section{HASIL PENELITIAN}

\section{ANALISIS DATA}

\subsection{Pengujian Asumsi Klasik}

Pengujian terhadap ada tidaknya terhadap pelanggaran asumsi-asumsi klasik yang merupakan dasar dalam model regresi linear berganda. Pengujian asumsi klasik yang digunakan dalam penelitian ini meliputi uji normalitas, uji multikolineritas, uji heteroskedastisitas, dan uji autokolerasi

\section{Uji Normalitas}

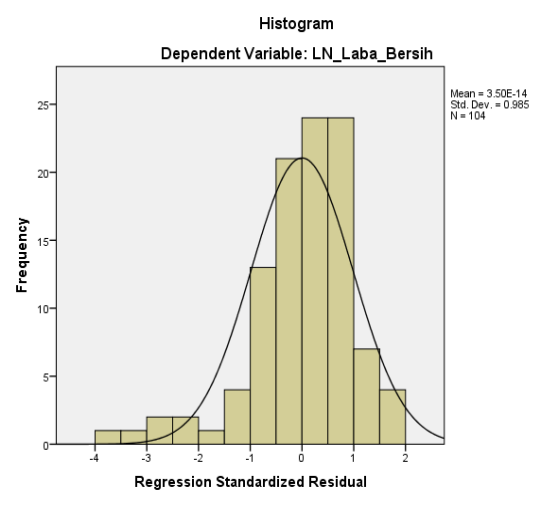

\section{Uji Normalitas Histogram}

Hasil grafik histogram setelah transformasi menunjukkan adanya pola data yang baik dimana pada gambar bisa dilihat dengan tampilan pola data menunjukkan pola data yang mengikuti garis ketentuan kurva berbetuk lonceng.

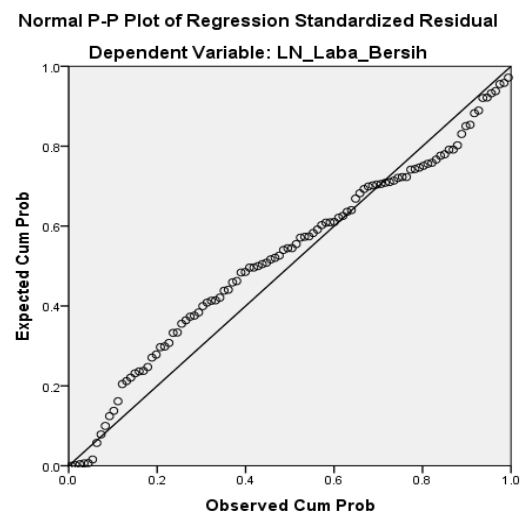

\section{Uji Normalitas P-P Plot Setelah Transformasi}

Berdasarkan gambar di atas, hasil uji normalitas probability plot ini menunjukkan adanya pola data baik dengan mengikuti pola garis ketentuan atau garis

\begin{tabular}{|c|c|c|}
\hline & & $\begin{array}{c}\text { Unstandardized } \\
\text { Residual }\end{array}$ \\
\hline $\mathrm{N}$ & & 104 \\
\hline \multirow{3}{*}{ Normal Parameters ${ }^{\mathrm{a}, \mathrm{b}}$} & Mean & $0 \mathrm{E}-7$ \\
\hline & Std. Deviation & .53298679 \\
\hline & Absolute & .104 \\
\hline \multirow[t]{2}{*}{ ost Extreme Differences } & Positive & .080 \\
\hline & Negative & -.104 \\
\hline Kolmogorov-Smirnov Z & & 1.056 \\
\hline Asymp. Sig. (2-tailed) & & .215 \\
\hline \multicolumn{3}{|c|}{ a. Test distribution is Normal. } \\
\hline \multicolumn{3}{|l|}{ b. Calculated from data. } \\
\hline Hasil & One & Sample \\
\hline
\end{tabular}
diagonal seperti gambar di atas. Dengan demikian maka hasil uji normalitas baik dengan analisis grafik maupun dengan analisis statistik memenuhi syarat karena data telah berdistribusi normal.

\section{Uji Normalitas Kolmogorov-Smirnov}

TransformasiOne-Sample Kolmogorov-Smirnov Test

Kolmogorov-Smirnov Test dapat dilihat bahwa nilai Kolmogrov-Smirnov (K-S) adalah sebesar 1,056. Dengan nilai signifikan Asmp.Sig (2-tailed) pada data yaitu sebesar 0,215. Data hasil uji normalitas menunjukkan nilai Asymp.Sig (2-tailed) > nilai probabilitas $(0,05)$ maka 
data pada penelitian ini berdistribusi normal.

Uji Multikolonearitas

\begin{tabular}{|c|c|c|c|}
\hline \multicolumn{4}{|c|}{ Coefficients $^{a}$} \\
\hline \multicolumn{2}{|c|}{ Model } & \multicolumn{2}{|c|}{ Collinearity Statistics } \\
\hline & & Tolerance & VIF \\
\hline \multirow{3}{*}{1} & BI_Rate & .996 & 1.004 \\
\hline & DPK & .930 & 1.075 \\
\hline & NIM & .932 & 1.073 \\
\hline \multicolumn{4}{|c|}{ a. Dependent Variable: Laba_Bersih } \\
\hline
\end{tabular}

Dari hasil perhitungan SPSS maka diperoleh nilai VIF < 10 dan nilai tolerance $>0,1$ dan hal itu menunjukkan bahwa tidak terdapat gejala multikolineritas.

\section{Uji Autokorelasi}

\begin{tabular}{|l|c|r|r|r|r|}
\hline \multicolumn{5}{|c|}{ Model Summaryb } \\
\hline Model & $\mathrm{R}$ & R Square & $\begin{array}{c}\text { Adjusted } \\
\mathrm{R} \\
\text { Square }\end{array}$ & $\begin{array}{c}\text { Std. Error } \\
\text { of the } \\
\text { Estimate }\end{array}$ & $\begin{array}{r}\text { Durbin- } \\
\text { Watson }\end{array}$ \\
\hline 1 & $.960^{\mathrm{a}}$ & .922 & .919 & .54092 & 2.177 \\
\hline a. Predictors: (Constant), LN_NIM, LN_BI_Rate, LN_DPK \\
\hline \multicolumn{2}{|l}{ b. Dependent Variable: LN_Laba_Bersih } \\
\hline
\end{tabular}

$$
\text { Hasil uji Durbin-Watson }
$$

menunjukkan nilai sebesar 2,177; sedangkan dalam tabel DW untuk " $\mathrm{k}$ " $=3$ ( $\mathrm{k}=$ jumlah variabel bebas) dan $\mathrm{N}=104$ besar nilai dl (batas bawah) $=1,6217 \mathrm{dan} \mathrm{du}$ (batas atas) $=1,7402 ; 4-\mathrm{dl}=2,3783$ dan 4 $-\mathrm{du}=2,2598$. Dengan melihat kriteria pada pedoman Durbin-Watson maka nilai du < $\mathrm{dw}<4$-du atau 1,7402 < 2,177<2,2598 maka dari hasil uji Autokorelasi dapat diambil kesimpulan tidak terjadi autokorelasi positif dan negatif.

\section{Uji Heteroskedastisitas}

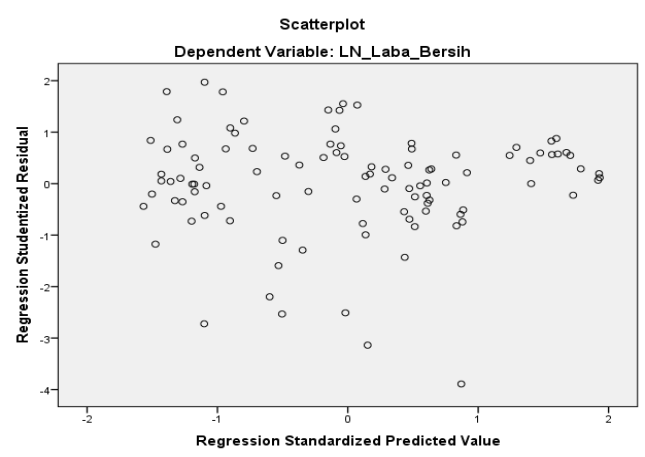

Dari grafik scatterplot terlihat bahwa titik-titik menyebar secara acak baik di atas maupun di bawah angka nol (0) pada sumbu Y, tidak berkumpul di satu tempat, sehingga dari grafik scatterplot dapat disimpulkan bahwa tidak terjadi heteroskedastisitas pada model regresi.

\section{Analisis Regresi Linear}

Hasil Persamaan Regresi Linear

\section{Berganda}

\begin{tabular}{|c|c|c|c|c|c|c|}
\hline \multicolumn{7}{|c|}{ Coefficients $^{\mathrm{a}}$} \\
\hline \multirow{2}{*}{\multicolumn{2}{|c|}{ Model }} & \multicolumn{2}{|c|}{$\begin{array}{c}\text { Unstandardized } \\
\text { Coefficients }\end{array}$} & \multirow{2}{*}{$\begin{array}{c}\text { Standardized } \\
\text { Coefficients }\end{array}$} & \multirow[t]{2}{*}{$\mathrm{t}$} & \multirow[t]{2}{*}{ Sig. } \\
\hline & & B & $\begin{array}{l}\text { Std. } \\
\text { Error }\end{array}$ & & & \\
\hline \multirow{4}{*}{1} & (Constant) & -10.370 & 1.250 & & -8.293 & .000 \\
\hline & LN_BI_Rate & .353 & .262 & .038 & 1.349 & .180 \\
\hline & LN_DPK & 1.122 & .037 & .888 & 30.373 & .000 \\
\hline & LN_NIM & 1.034 & .155 & .195 & 6.679 & .000 \\
\hline \multicolumn{7}{|c|}{ a. Dependent Variable: LN_Laba_Bersih } \\
\hline
\end{tabular}

Hasil persamaan regresi pada tabel IV.11 diatas dapat diperoleh nilai konstanta dan koefisien regresi dari masing-masing variabel, sehingga persamaan model regresi linier berganda pada penelitian ini dapat diuraikan menjadi :

\section{LN_Laba bersih $=-10,370+0,353$ LN_BI \\ Rate + 1,122 LN_Dana Pihak Ketiga + 1,034 LN_Net Interest Margin}

Makna dari persamaan regresi linier berganda diatas adalah :

1. Nilai konstanta sebesar $-10,370$ menyatakan bahwa jika BI Rate, 
Dana Pihak Ketiga dan Net Interest Margin bernilai 0 maka laba bersih sebesar -10,370.

2. Nilai koefisien regresi BI Rate sebesar 0,353 dan bernilai positif menyatakan bahwa setiap kenaikan 1 persen BI Rate akan menyebabkan peningkatan laba bersih sebesar 0,353 persen.

3. Nilai koefisien regresi Dana Pihak Ketiga sebesar 1,122 dan bernilai positif menyatakan bahwa setiap kenaikan 1 persen Dana Pihak Ketiga akan menyebabkan peningkatan laba bersih sebesar 1,122 persen.

4. Nilai koefisien regresi Net Interest Margin sebesar 1,034 dan bernilai positif menyatakan bahwa setiap kenaikan 1 persen Net Interest Margin akan menyebabkan peningkatan laba bersih sebesar 1,034 persen.

\subsection{Koefisien Determinasi}

Uji Koefisien Determinasi

\begin{tabular}{|c|c|c|c|c|}
\hline \multicolumn{5}{|c|}{ Model Summary } \\
\hline Model & $\mathrm{R}$ & R Square & $\begin{array}{l}\text { Adjusted R } \\
\text { Square }\end{array}$ & $\begin{array}{l}\text { Std. Error of } \\
\text { the Estimate }\end{array}$ \\
\hline 1 & $.960^{\mathrm{a}}$ & .922 & .919 & .54092 \\
\hline \multicolumn{5}{|c|}{ a. Predictors: (Constant), LN_NIM, LN_BI_Rate, LN_DPK } \\
\hline
\end{tabular}

Hasil Uji Koefisien Determinasi diperoleh nilai Adjusted $R$ square sebesar 0,919 . Artinya variasi variabel dependen laba bersih yang dapat dijelaskan oleh variabel independen BI Rate, Dana Pihak Ketiga dan Net Interest Margin adalah sebesar 91,9 persen. Sedangkan sisanya sebesar 8,1 persen dijelaskan oleh variabelvariabel independen lainnya diluar penelitian ini, misalnya BOPO.

Uji Simultan (F)

ANOVA $^{a}$

\begin{tabular}{|c|c|c|c|c|c|c|}
\hline \multicolumn{2}{|c|}{ Model } & Sum of & df & Mean & $\mathrm{F}$ & Sig. \\
\hline \multirow{3}{*}{1} & Regression & 344.546 & 3 & 114.849 & 392.514 & $.000^{\mathrm{b}}$ \\
\hline & Residual & 29.260 & 100 & 293 & & \\
\hline & Total & 373.805 & 103 & & & \\
\hline \multicolumn{7}{|c|}{ a. Dependent Variable: LN_Laba_Bersih } \\
\hline \multicolumn{7}{|c|}{ b. Predictors: (Constant), LN_NIM, LN_BI_Rate, LN_DPK } \\
\hline
\end{tabular}

Hasil uji signifikansi secara simultan pada tabel IV.13 diatas diperoleh nilai Fhitung sebesar 392,514. Pada derajat bebas $1(\mathrm{df} 1)=\mathrm{k}=3$, dan derajat bebas 2 $($ df 2$)=\mathrm{n}-\mathrm{k}=104-3-1=100$, dimana $\mathrm{n}=$ jumlah sampel, $\mathrm{k}=$ jumlah variabel, nilai Ftabel pada taraf kepercayaan signifikansi 0,05 adalah 2,70. Dengan demikian nilai Fhitung $=392,514>$ Ftabel $=2,70$ dengan tingkat signifikansi $0,000<0,05$. Maka Ha diterima artinya BI Rate, Dana Pihak Ketiga dan Net Interest Margin secara simultan berpengaruh signifikan terhadap laba bersih pada perusahaan sektor perbankan yang terdaftar di Bursa Efek Indonesia pada tahun 2013 - 2016.

\section{Uji Parsial (t)}

\begin{tabular}{|c|c|c|c|c|c|c|}
\hline \multicolumn{7}{|c|}{ Coefficients $^{a}$} \\
\hline \multirow{2}{*}{\multicolumn{2}{|c|}{ Model }} & \multicolumn{2}{|c|}{$\begin{array}{c}\text { Unstandardized } \\
\text { Coefficients }\end{array}$} & \multirow{2}{*}{$\begin{array}{c}\text { Standardized } \\
\text { Coefficients } \\
\text { Beta }\end{array}$} & \multirow[t]{2}{*}{ t } & \multirow[t]{2}{*}{ Sig. } \\
\hline & & B & $\begin{array}{l}\text { Std. } \\
\text { Error }\end{array}$ & & & \\
\hline \multirow{4}{*}{1} & (Constant) & $10.370^{-}$ & 1.250 & & -8.293 & .000 \\
\hline & LN_BI_Rate & .353 & .262 & .038 & 1.349 & .180 \\
\hline & LN_DPK & 1.122 & .037 & .888 & 30.373 & .000 \\
\hline & LN NIM & 1.034 & .155 & .195 & 6.679 & .000 \\
\hline
\end{tabular}

Hasil uji signifikansi secara parsial diatas diperoleh nilai ttabel untuk probabilitas 0,05 pada derajat bebas df $=100$ adalah sebesar 1,98397. Dengan demikian hasil dari Uji t dapat dijelaskan sebagai berikut :

1. Hasil perhitungan uji $t$ secara parsial diperoleh nilai thitung BI Rate sebesar 1,349 dengan nilai signifikan sebesar $0,180>0,05$. Nilai thitung < ttabel atau 1,349 < 1,98397, maka H0 diterima artinya BI Rate tidak berpengaruh terhadap laba bersih pada perusahaan sektor perbankan yang terdaftar di Bursa Efek Indonesia pada tahun 2013 - 2016. 
2. Hasil perhitungan uji $\mathrm{t}$ secara parsial diperoleh nilai thitung Dana Pihak Ketiga sebesar 30,373 dengan nilai signifikan sebesar $0,000<0,05$. Nilai thitung > ttabel atau 30,373>1,98397, maka Ha diterima artinya Dana Pihak Ketiga berpengaruh positif dan signifikan terhadap laba bersih pada perusahaan sektor perbankan yang terdaftar di Bursa Efek Indonesia pada tahun 2013 - 2016.

3. Hasil perhitungan uji $\mathrm{t}$ secara parsial diperoleh nilai thitung Net Interest Margin sebesar 6,679 dengan nilai signifikan sebesar $0,000<0,05$. Nilai thitung > ttabel atau 6,679>1,98397, maka Ha diterima artinya Net Interest Margin berpengaruh positif dan signifikan terhadap laba bersih pada perusahaan sektor perbankan yang terdaftar di Bursa Efek Indonesia pada tahun 2013 - 2016.

\section{KESIMPULAN}

BI Rate, Dana Pihak Ketiga dan Net Interest Margin, secara simultan berpengaruh signifikan terhadap Laba Bersih pada perusahaan sektor perbankan yang terdaftar di Bursa Efek Indonesia pada tahun 2013 - 2016.

\section{DAFTAR PUSTAKA}

Defri. 2012. Pengaruh Capital Adequacy Ratio (CAR), Likuiditas dan Efisiensi Operasional Terhadap Profitabilitas Perusahaan Perbankan yang Terdaftar di BEI. Jurnal. Fakultas Ekonomi Universitas Negeri Padang.

Sudirman, I Wayan. 2013. Manajemen Perbankan. Bandung : Penerbit Salemba Empat

Ghozali, Imam.2013. Aplikasi Analisis Multivariate Dengan Program
IBM SPSS. Jakarta : Penerbit Universitas Diponegoro

Wira, Desmon. 2014. Teori akuntansi. Jakarta : Raja Grafindo Persada.

Ikhsan. 2012. Rahasia Cermat dan Mahir Menganalisis Laporan Keuangan. Jakarta : PT Grasindo.

Kasmir. 2011. Analisis Laporan

Keuangan. Cetakan Keempat. Jakarta : Penerbit Rajagrafindo Persada

Nuritomo. 2014. Bank dan Lembaga

Keuangan Lainnya Edisi 3. Jakarta : Penerbit Salemba Empat.

Naf'an, 2014. Ekonomi Makro(Tinjauan

Ekonomi Syariah). Jakarta :

Penerbit Graha Ilmu.

Hendro, Tri. 2014. Bank dan Institusi keuangan Non Bank di Indonesia. Jakarta : Penerbit UPK STIM YKPN.

Sopyan. 2016. Analisis Kristis atas Laporan Keuangan . Jakarta : Penerbit Rajagrafindo

www.bi.go.id

Ikatan Bankir Indonesia. 2017 